\title{
MANUFACTURING AND CONSUMPTION OF AGRICULTURAL PRODUCTS AS A TOOL OF FOOD SECURITY MANAGEMENT IN RUSSIA
}

\author{
Aleksey F. Rogachev1, \\ Anna V. Shokhnekh², \\ Tamara I.Mazaeva ${ }^{1}$
}

1Volgograd State Agrarian University, Volgograd, Russia, ${ }^{2}$ Research Economic Models of Management, Accounting and Taxation LLC, Volgograd Russia

\begin{abstract}
The purpose of the article is to develop instrumentarium for determination of the level of food security. In order to achieve the set goal, the authors use method of monitoring and economic \& mathematical modeling of manufacture and consumption of agricultural products. In the process of the research, the authors test this method by the example of modern Russia and determine the existence of the problem of food security. In order to solve this problem, the authors develop recommendations for stabilization of agricultural production, as a basis of country's food security. The authors also conduct analysis of agricultural development of developed countries and determine primary tasks, solution of which will stipulate provision of the required level of food security. As a result of the research, the authors come to the conclusion that the developed recommendations can be directions of unified state approach to solving the problem of achievement of food security and formation of agrarian policy. At that, it should be noted that policy which is aimed at achievement of national-level goal cannot be formed without relevant informational provision. Therefore, agriculture authorities must possess full, high-quality, and actualized information. Elements of state policy in the sphere of achievement of food security can stipulate achieving indicators which are determined by national doctrine and form optimal level of cooperation of national agriculture production and foreign partners.

Keywords: food security, production and consumption of agricultural products, economic \& mathematical modeling, monitoring.
\end{abstract}

\section{Introduction}

New political system of the Russian Federation and emerging global economic relations required specifying the notion "food security", its main principles, and peculiarities. National concept of state policy in the sphere of provision of state security is based on the national Doctrine of food security of the Russian Federation, adopted by the Order of the President of the Russian Federation dated January 30, 2010, No. 120.

It defines the notion of food security as a "state of economy, at which food security of the country is ensured, and accessibility of food for population in quantity required for active and healthy life is guaranteed". One of the main criteria of food security is the level when not less than $80 \%$ of food products, consumed by population, are manufactured by the national agrarian sector (Mazaeva \& Rogachev, 2012).

Terms for achievement of food security indicators were also changed: the task for provision of the country with national food products was set, while purchase of imported food products has to be performed only in urgent, economically reasoned cases. Performance of this task requires rethinking the complex of measures of state policy: on the one hand, real market does not stand administrative state interference, and, on the other hand, its state regulation - as the global practice shows - is necessary (Popkova et al., 2015a).

Thus, one of the most important tasks of economic science is development of measures of stimulating and limiting character which create economic conditions which guarantee food security and ensure systemic and strategic formation of state policy for the purpose of increase of living standards in view of international experience. 


\section{Materials and method}

Theoretical foundation of the research consists of the works of modern scientists in the sphere of study of the problem of food security - in particular, works of such authors as (Garthwaite et al., 2015), (He, 2015), (Jacknowitz et al., 2015),(Maitra \& Rao, 2015), etc.

Also, the article uses the materials of the research of issues of manufacture and consumption of agricultural products, which include the works of (Bernardes, 2015), (Medernach \& Burnod, 2013), (Grouiez, 2012), (Bazylyuk \& Mynenko, 2010), etc.

Overview of the literature on the topic of this research showed that despite a large number of materials by various authors on the issues of manufacture and consumption of agricultural products and high level of study of the problem of food security, these topics are studied separately, which leads to absence of comprehensive theoretical \& methodological basis for solving these problems.

In particular, instrumentarium of monitoring and economic \& mathematical modeling of manufacture and consumption of agricultural products and of food security management is not sufficiently elaborated, which requires further research in this sphere.

This research is devoted to development of such instrumentarium. The following general scientific methods are used: analysis, synthesis, induction, deduction, graphical presentation of information, and special methods of research in the sphere of economics - statistical analysis of information and method of economic \& mathematical modeling,

This research offers to use proprietary model of monitoring of manufacture and consumption of agricultural products for food security management, which has the following form:

$$
\mathrm{FS}=(\text { Manuf } / \text { Cons }) * 100 \%
$$

where FS - indicator of food security;

Manuf - volume of manufacture of agricultural products;

Cons - volume of consumption of agricultural products.

As is seen from formula (1), the presented model of monitoring of manufacture and consumption of agricultural products for management of national food security supposes determination of manufacture's share in the structure of agricultural products consumption. The received value of the indicator of food security is evaluated with the help of classification table (Table 1) with linguistic evaluative terms for further realization of fuzzy set modeling.

Table 1. Table for evaluation of food security indicator

\begin{tabular}{|l|l|l|l|l|l|}
\hline Characteristics of & \multicolumn{5}{|l|}{ Value of FS level } \\
\cline { 2 - 6 } & $\leq 70 \%$ & $71-79 \%$ & $80-85 \%$ & $86-90 \%$ & $\geq 90 \%$ \\
\hline Linguistic term & crisis & critical & normal & good & excellent \\
\hline \begin{tabular}{l} 
Type $\begin{array}{l}\text { membership } \\
\text { function }\end{array}$ \\
\hline
\end{tabular} & S-shaped & triangular & triangular & triangular & S-shaped \\
\hline
\end{tabular}

As is seen from Table 1, five intervals are distinguished within the given model. Situation when value of food security indicator constitutes $80-85 \%$ is considered to be normal. This shows that more than $4 / 5$ of agricultural products consumption is covered by internal production, which reflects acceptable dependence on import.

Situation is considered to be good when the value of food security indicator constitutes $86-90 \%$. This shows low dependence on import. The state of affairs is excellent when more than $90 \%$ of consumption of agricultural products is covered by internal production, which shows almost complete absence of import dependence. 
Critical situation takes place when the value of food security indicator constitutes $71-79 \%$, which shows high dependence on imports. A crisis starts when less than $70 \%$ of agricultural products consumption is covered by internal production. This shows excessive dependence on import and loss of food sovereignty.

The described algorithm of evaluation of results of monitoring of manufacture and consumption of agricultural products and fuzzy set model can be used for determining the level of food security of national economy on the whole and of separate regions. In is possible to build generalized indicators of FS on the basis, for comparing to national level or regional level of FS of other regions or countries of the world.

\section{Results}

Modern Russia is at initial stage of provision of real food security, when conceptual foundations of development of corresponding economic relations are set (Rogachev \& Shokhnekh, 2015). Despite certain revival of agriculture over recent years, trend of its dynamics is not stable (Fig. 2).
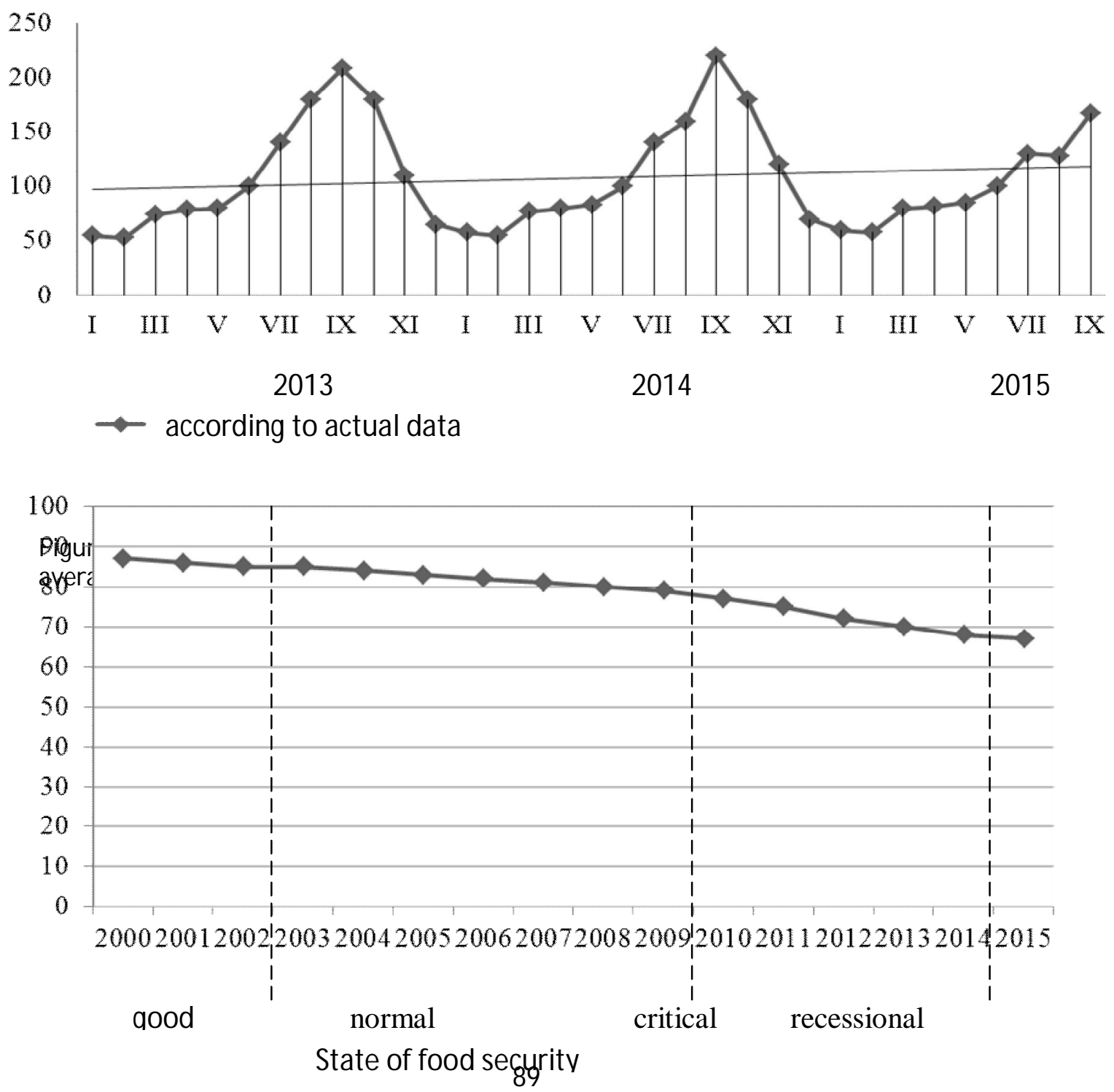
Let us conduct evaluation of food security in modern Russia with the help of the developed model of monitoring of manufacture and consumption of agricultural products (Fig. 3).

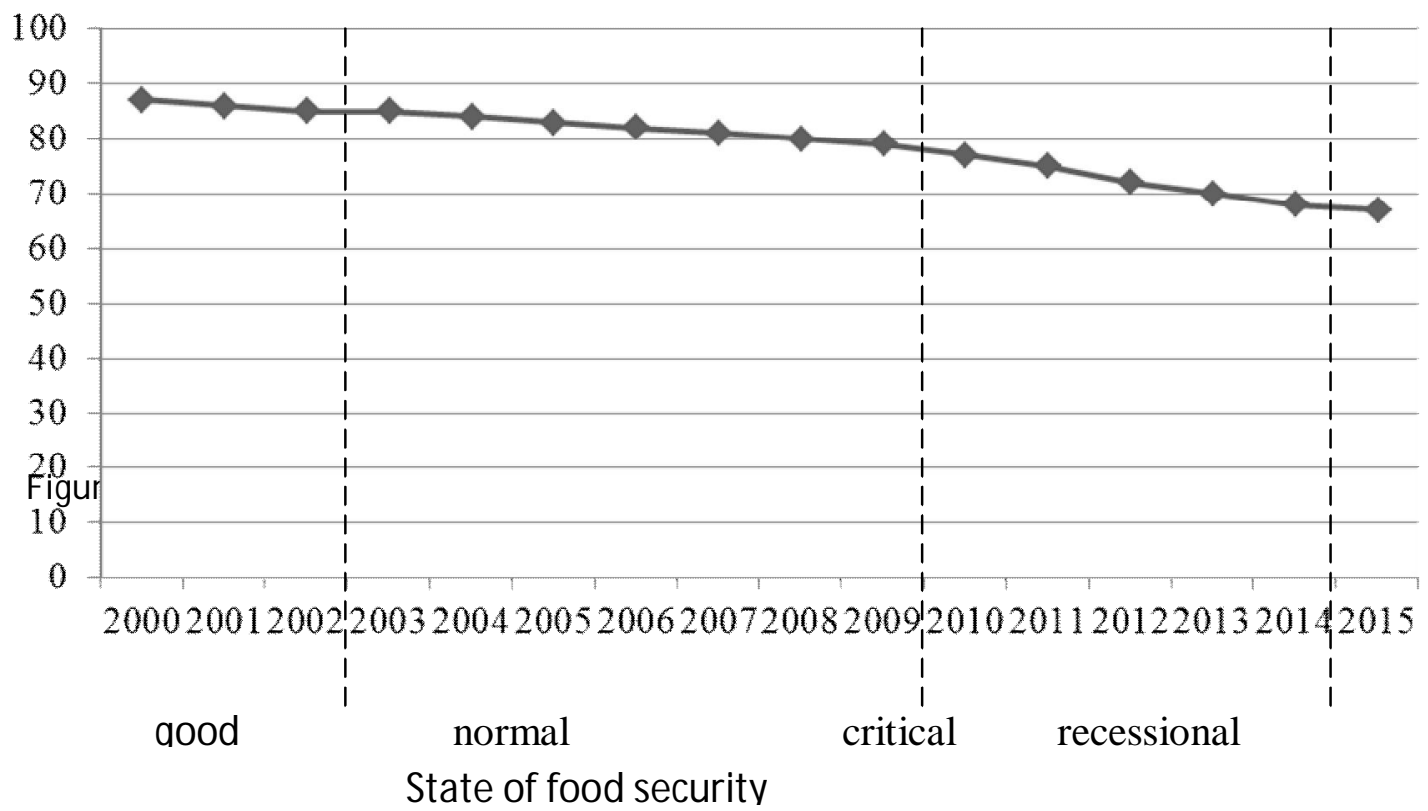

As is seen from Fig. 3, state of food security in Russia has been worsening with each year over 2000-2015. Thus, until 2002, the state was good, in 2002-2009 - normal, in 2009-2014 - critical, and since 2014, the state has been recessional.

Despite measures taken by the government and agro-industrial complex authorities, industrial production of the country hasn't yet overcome the long recessional state, caused by economic transformations of 1990's. Formation of multi-aspect agrarian economy didn't allow solving problems of agriculture (Rogachev, 2013).

However, with reconsideration of agrarian policy in 2000's, there have been certain positive tendencies in the sphere on the whole - in particular, in 2003-2009, gross product of agriculture grew by $35.5 \%$. Analysis of dynamics of production of crop growing products for the period showed that in economies of all categories production of corn began growing in 2000, reaching the maximum of 108,179,000 tons in 2008, which is by $32.8 \%$ more than production of previous tear and by $65.4 \%$ higher than the level of 2000 . During that period, production of sunflower seeds grew by 2 times, of sugar beet (factory) grew by almost 2.1 times (Rogachev \& Protsyuk 2013).

Reduction of indicators for crop growing in 2009-2010 had an objective character - it was a consequence of drought in 16 regions in 2009 and catastrophic drought of 2010 in 43 subjects of the Russian Federation. At the stage of stabilization of agricultural production as a basis for food security of the country, the following measures are required (Rogachev \& Fedorova, 2014):

- systemic study of foundations of food security and factors which influence it;

- attraction of state and commercial organizations, R\&D institutes, authorities of the subjects of the Russian Federation, interested parties, specialists, practitioners of agricultural enterprises, and society for solving this problem;

- comprehensive accounting of existing global experience on creation of 
system and elements of food security and simultaneous observation of rights of economic subjects;

- prevention of mistakes and rash actions which violate integrity of economic system of the Russian Federation and its connection with the global economy;

- scientific forecast of consequences of measure of economic interference;

- coordination of mutual actions with partners, primarily from countries of the near abroad;

- systemic monitoring of the state of Russian food market an quick reaction to price movements;

- development of measures for use of competitive advantages of main regions which produce agricultural products (especially important agrarian territories).

Taking into account complexity of the researched problem - in particular, of its certain aspects which determine the level of achievement of indicators of food security - it should be noted that this task could be solved by the Russian Federation, with its developed system of management, foundations of custom regulation law, and foundations of agricultural production (Popkova et al., 2015b).

Despite the collapse of 1990's, Russia preserved the system of agricultural production; state support strengthened over recent years, and agrarian sphere was proclaimed one of top-priorities, which gives certain hope for achieving in near future the desired level of food security (Rogachev, 2009).

It should be acknowledged that over the last years, there have been mistakes in the sphere of regulation of agrarian relations. Old forms and methods of economic management preserved - but they do not conform to modern requirements; on the other hand, no innovations have appeared which would fully satisfy current needs in food provision. All this leads to necessity for "manual management", which is nowhere close to market methods.

Cardinal measures of economic nature and state support for agrarian sphere are necessary - as destroyed communal households and most of privatized agricultural enterprises are not able to solve the problem by themselves. It is necessary to choose the further direction of development of agro-food complex, based on national interest, traditions, and past positive experience. Despite complex agro-climate conditions, Russia has been successfully coping with manufacture of agricultural products and has refrained from large import purchases, with certain period of exporting food products.

In order to provide the level of food security, which is determined by the national doctrine, it is necessary to create conditions which would allow Russian agricultural manufacturers not only to produce, but also to process, store, and sell agricultural products, thus receiving stable profit.

Formation of these conditions is possible on the basis of stable and legally formed "rules of the game" and systemic growth of state support for development of agroindustrial complex and rural territories. Top-priority of agricultural production has to be proclaimed and, moreover, supported in practice. This task is being solved by the State program "Development of agriculture and regulation of agricultural products markets, raw materials, and food for 2008-2012 годы" and by the developed State program, for the next five years and until 2020.

Analysis of development of agriculture of developed countries allows formulating primary tasks, solving of which will stipulate the provision of required level of food security (Mazaeva \& Rogachev, 2015):

- successful conduct of technical \& technological modernization of agro-food 
sphere;

- increase of purchasing ability of population; reduction of tax load; balance of market of food purchases; elimination of disparity of prices for agricultural products and consumed resources of industrial production;

- organization of modern trade service, including for rural population;

- development of various forms of agricultural consumer cooperation; provision of state guarantees for agricultural manufacturers for a right of land use and profitable conditions of products realization;

- solving personnel, socio-cultural, and educational problems of rural areas, increase of living standards of rural population.

Let us view some of the above tasks in detail. Taxes should allow any agricultural manufacturer not only to exist but to ensure expanded reproduction, as high tax rates exclude positive result of any economic activities.

Price disparity, which emerged during the reformation period and exists now, lead to "scissors" between expenses for agricultural products manufacture and assets received from its sales. However, quick change of prices for agricultural products may lead to danger of social crisis, as income level of main part of population is still low. There's a need for full government support for agricultural products manufacturer. Very often, peasants receive money for their products later after its sale, though they need turnover assets for spring field works (Skiter et al., 2015).

Trade, as an important element of economic relations, stipulates formation of the level of food security. Custom policy of the state, aimed at protection of domestic manufacturer, is a mechanism which regulates foreign trade turnover. Besides, there is a necessity for flexible trade and purchase policy, the main task of which should be support for national agricultural products manufacturer and provision of guaranteed minimal prices of agricultural products purchase.

In order to provide state guarantees for agricultural manufacturers, it is necessary to ensure immunity of rural worker's property right for land, limit improper use of agricultural areas, organize system of control for rational use of lands, and forbid land speculations. It is important not to give all land into private property but to create conditions for its communal use (Rogachev, 2015).

Besides, it is advisable to preserve the possibility for state's interference with the process of irrational use of land plots of agricultural purpose; also, it is possible to give plots to efficient owners for conduct of agricultural production. In order to expand food market, it is advisable to use local possibilities at their maximum, including experience of consumer cooperation for manufacture of the most popular and demanded products, with involvement of resources of population's husbandries.

Graduates of agrarian universities and colleges of agricultural profile, which need decent conditions for life in rural areas, are the important potential for perfection of production, socio-cultural, and scientific \& educational provision of rural areas. Under the conditions when national project transforms into state program and agrarian policy becomes of top-priority, the role of science grows substantially.

Its developments are in high demand in fields and at farms of the country. Competitive agriculture of Russia can be formed only with full use of the newest innovational developments of fundamental and applied character. It is necessary to emphasize the importance for improvement of the system of agricultural manufacturers crediting. Current conditions do not urge for investing into agricultural production (Rogachev et al., 2015).

In case of losing current systems of specialization, cooperation, and agricultural equipment, one would require a lot of strength and assets for recovery of reproduction 
agricultural structure - far more than is needed for support for agriculture at present. Solving this problem depends on further development of the system of leasing for agrarian production.

\section{Conclusion}

It could be concluded that the above recommendations are direction for unified state approach to solving the problem of achievement of food security and formation of agrarian policy. At that, it should be noted that the policy which is aimed at achievement of national-level goal cannot be formed without relevant informational provision. Management bodies of agriculture should possess full, high-quality, and actualized information.

It should be noted that the discussed elements of state policy in the sphere of achievement of food security can stipulate achievement of indicators, set by the national doctrine and form optimal level of cooperation of the Russian agro-industrial complex and foreign partners.

The conducted research is limited by insufficient approbation of the developed instrumentarium for monitoring and economic \& mathematical modeling of production and consumption of agricultural products, as well as food security management. Therefore, practical use and generalization of experience of the use of this instrumentarium is a perspective direction for scientific research in this sphere.

\section{References}

Bannikova, N.V., Baydakov, A.N., Vaytsekhovskaya, S.S. (2015). Identification of Strategic Alternatives in Agribusiness. Modern Applied Science, 9(4): 344-353.

Bazylyuk, A.V., Mynenko, O.O. (2010). Economic consequences of international technical assistance in organization of agrobusiness in Ukraine. Actual Problems of Economics, (9), pp. 24-33.

Bernardes, J.A. (2015). Novas fronteiras do capital no Cerrado: Dinâmica e contradições da expansão do agronegócio na região centro-oeste, Brasil | [New frontiers of capital in the Brazilian Cerrado: The dynamics and contradictions of the expansion of agrobusiness in the central-west region]. Scripta Nova, 19.

Garthwaite, K.A., P.J. Collins and C.Bambra, 2015. Food for thought: An ethnographic study of negotiating ill health and food insecurity in a UK foodbank. Social Science and Medicine, 132(1): 38-44.

Grouiez, P. (2012). Des kolkhozes à l'agrobusiness en Russie. Etudes Rurales, 190 (2), 4962

He, J., 2015. Chinese public policy on fisheries subsidies: Reconciling trade, environmental and food security stakes. Marine Policy, 56(1): 106-116.

Jacknowitz, A., T. Morrissey and A. Brannegan, 2015. Food insecurity across the first five years: Triggers of onset and exit. Children and Youth Services Review, 53(1): 24-33.

Maitra, C. and D.S.P. Rao, 2015. Poverty-Food Security Nexus: Evidence from a Survey of Urban Slum Dwellers in Kolkata. Source of the World Development, 72(1): 308-325.

Mazaeva T.I. and A.F. Rogachev, 2012. Mathematical modeling and analysis of the processes of technological innovations implementation in the context of economic security. Economics and business, 5(28): 296-298.

Mazaeva T.I., Rogachev A.F. (2015). Economic and statistical modeling of manufacture of agricultural products for provision of food security. Economics and business, 9(4-1): 2124. 
Medernach, K., Burnod, P. (2013). Recompositions inattendues d'un système agraire malgache par l'agrobusiness | [Unexpected changes in a madagascan land system through agribusiness]. Etudes Rurales, 191 (1), 63-76.

Popkova, E.G., Chechina, O.S., Abramov S.A. (2015a). Problem of the Human Capital Quality Reducing in Conditions of Educational Unification. Mediterranean Journal of Social Sciences, 6(3), 95-100.

Popkova, E.G., Abramov, S.A., Ermolina, L.V., Gandin, E.V. (2015b). Strategic Effectiveness Evaluation as Integral Part of the Modern Enterprise Management. Asian social science, 11(20), 16-21.

Rogachev A.F., A.V. Shokhnekh, 2015. Genesis of mathematical models of econophysics as a path to food security. Audit and financial analysis, 1(1): 410-413.

Rogachev A.F. (2013). Methodological approaches to modeling of eco-economic security. Economics and business, 12-4 (41-4): 107-109.

Rogachev A.F., Fedorova Y.V.(2014). Fuzzy set modeling of eco-economic systems. Modern problems of science and education, 5(1): 317.

Rogachev A.F. (2009). Mathematical provision of the system of decision making on the basis of GIS-technologies. Bulletin of Nizhnevolzhsky Agrarian University complex: Science and higher professional education, 2(1): 144-151.

Rogachev A.F., Protsyuk M.P. (2013). Problems of modeling of economic effectiveness in knowledge economy. Bulleting of Adygeya State University. Series 5: Economics, 4 (131): 189-195.

Rogachev A.F, Mazaeva T.I. (2015). Methodological approaches to systemic modeling of provision of regional food security. Economics and business, 9(4-1): 5-8.

Rogachev A. (2015). Economic and Mathematical Modeling of Food Security Level in View of Import Substitution. Asian Social Science, 11(20): 178-184.

Rogachev A., Mazaeva T., Egorova E. (2015). Economic Mechanisms for Managing Food Security in the System "Production-Consumption-Import". Asian Social Science, 11(20): 185-193.

Skiter N., Rogachev A.F., Mazaeva T.I. (2015). Modeling Ecological Security of a State. Mediterian Journal of Social Science, 6(3): 192-195.

Journal Website: http:/ / www.usc.es/ econo/ RGE/ benvidag.htm 